\title{
Experimental Contact Infection of NOD/ShiJic- scid Mice with Pasteurella pneumotropica
}

\author{
Eiichi Kawamoto ${ }^{1}$, Hiraku Sasaki ${ }^{2 *}$, Takao Kanai ${ }^{3}$ and Hidehiro Ueshiba ${ }^{3^{*}}$ \\ ${ }^{1}$ Animal Research Center, Tokyo Medical University, Shinjuku, Tokyo, 160-8402 \\ ${ }^{2}$ Department of Health Science, Juntendo University, Inzai, Chiba, 260-1695 \\ ${ }^{3}$ Institute of Laboratory Animals, Tokyo Women's Medical University, Shinjuku, Tokyo, 162-8666
}

Received: 21 February, 2017; Accepted: 31 March, 2017; Published: 14 April, 2017

*Corresponding author: Hiraku Sasaki, Department of Health Science, Juntendo University, Inzai, Chiba, 260-1695; E-mail: hirakus@juntendo. ac.jp

\begin{abstract}
Background: Pasteurella pneumotropica is a Gram-negative bacterium that infects the laboratory rodents. In immunodeficient animals, $P$. pneumotropica infection develops mild to severe or lethal diseases. However, little is known about the transmissibility and pathogenesis of $P$. pneumotropica in immunodeficient mice. In this study, to assess transmissibility and its pathological conditions by $P$. pneumotropica, experimental contact infection model of NOD/Shijic-scid mice was examined with clinical and pathological approaches.
\end{abstract}

Findings: The bacteria could infect NOD/Shijic-scid mice by experimental contact, and half of the infected mice exhibited a decrease in body weight with subsequent death. These mice displayed lung abscess lesions. P. pneumotropica was isolated from the lower respiratory tract of these mice.

Conclusions: This experimental contact model achieved to facilitate $P$. pneumotropica transmissibility and form similar pathological process same as directly infected mice.

\section{Introduction}

Pasteurella pneumotropica is a gram-negative, nonmotile, short rod-shaped bacterium. Based on $16 \mathrm{~S}$ rDNA sequence analysis, this species belongs to the rodent cluster, but not to Pasteurella sensu stricto [1]. The natural hosts of these bacteria are rodents, including mice, rats, hamsters, and gerbils [2-3]. This species colonizes the upper respiratory tract, conjunctiva, intestines, and reproductive tissues of animals [4]. This bacterium causes rodent pasteurellosis, including fatal pneumonia, sepsis and conjunctivitis. In immunocompetent animals, clinical diseases are not commonly observed. However, immunodeficient animals develop mild to severe or lethal diseases [5-10].

It is important to develop an experimental infection model for clarification of the transmissibility and pathogenesis of
P. pneumotropica. There have been some reports of experimental intranasal inoculation models of $P$. pneumotropica; however, these models might not resemble natural infection $[4,11,12]$ Experimental contact infection resembles natural infection more so than experimental inoculation models $[13,14]$. There have been some studies on the transmission of this species; however, to our knowledge, experimental contact infection of $P$. pneumotropica has not been reported $[15,16]$. In our previous study, NOD/shijicscid/Jcl mice with multiple defects in adaptive and non-adaptive immunological functions were intranasally infected with bacteria [7]. Herein, some mice displayed lung abscesses and died. The findings of our study showed that P. pneumotropica resided in the nasal cavity of all inoculated mice up to 35 days post-inoculation. This suggests that we achieved experimental contact infection with P. pneumotropica in mice.

The purpose of the present study was to examine whether P. pneumotropica could be transmitted to mice by contact under experimental conditions and cause disease.

\section{Materials and Methods}

\section{Animals and ethics statement}

Four- to five-week-old female NOD/ShiJic-/scid/Jcl mice were obtained from CLEA, Japan, Inc., Tokyo, Japan. Mice were housed using sterilized spruce bedding (White Flakes, Oriental Yeast Co., Ltd, Tokyo, Japan) in sterilized cages (Clean S TPX cage, CLEA Japan, Inc, Tokyo, Japan) within a laminar airflow cabinet (Okazaki Sangyo Co., Ltd, Tokyo, Japan). The animals were fed sterilized standard chow pellets (FR-1, Funabashi Farm Co. Ltd, Chiba, Japan) and water was available ad libitum. The room was maintained at $24 \pm 2{ }^{\circ} \mathrm{C}$ and $50 \pm 10 \%$ relative humidity with a $12 \mathrm{~h}$ dark-light cycle. The mice tested negative for Sendai virus, mouse hepatitis virus, Mycoplasma pulmonis, Corynebacterium kutscheri, Clostridium piliforme, P. pneumotropica, Pseudomonas aeruginosa, Salmonella spp., and Syphacia spp. All mice were between 5 and 
6 weeks of age when inoculated with P. pneumotropica or upon contact with inoculated mice. All animal experimental procedures were performed in accordance with institutional, science community, and national guidelines for animal experimentation. In addition, the Institutional Animal Care and Use Committee (IACUC) of Tokyo Medical University approved all procedures described here (No. 381).

\section{Preparation of P. pneumotropica inoculum}

P. pneumotropica strain ATCC 35149 (type Jawetz) was used to prepare the inoculum. The strain possessed outermost surface materials, which may be pili, on the bacterial cells and belonged to group two based on biochemical and genetic characteristics $[17,18]$. This strain produces RTX toxins PnxIA, IIA, and IIIA, and its draft genome sequence has been revealed $[19,20]$. The strain was thawed from frozen stocks $\left(-80^{\circ} \mathrm{C}\right)$ and grown overnight on $5 \%$ horse blood agar plates (Sanko Junyaku Co. Ltd, Tokyo, Japan) and checked for purity. The organism was cultured in brain heart infusion (BHI) broth (Eiken Chemical Co., Ltd, Tokyo, Japan) at $37^{\circ} \mathrm{C}$ for $24 \mathrm{~h}$.

\section{Experimental design}

Twelve NOD/ShiJic-/-scid/Jcl mice were divided into three treatment groups as follows. Group I mice: four mice were inoculated intranasally with P. pneumotropica at a dose of 107 CFU in $25 \mu \mathrm{L}$ BHI broth using a micropipette and two mice were kept in each of cage A (mice: Nos. 1 and 2) and B (mice: Nos. 3 and 4). Group II: three scid mice were put in each of cage A (mice: Nos. 5, 6, and 7) and B (mice: Nos. 8, 9, and 10). Group III: one mouse (No. 11) was sham-inoculated with BHI broth as described above and one mouse (No. 12) was non-treated. These mice were kept in cage $\mathrm{C}$.

Two mice each from group I and II were euthanized by cervical dislocation 35 days after inoculation or contact. One mouse in each from group I and II, and two mice from group III were euthanized in the same manner 70 days after inoculation or contact.

Each mouse was weighed weekly. The mice were examined pathologically and bacteriologically at 35 and 70 days after inoculation or contact. Dead mice were processed in a similar manner as described above.

\section{P. pneumotropica isolation}

At necropsy, specimens from the nasal cavity, conjunctiva, oral cavity, oropharynx, trachea, lungs, and heart blood were streaked onto horse blood agar plates and incubated at $37^{\circ} \mathrm{C}$ for $24-48 \mathrm{~h}$. Bacterial identification as P. pneumotropica included the following criteria: Gram-negative coccobacillus, positive results for glucose, ornithine decarboxylase, urease, nitrate reductase, indole production, catalase, oxidase, and $\beta$-galactosidase, and negative results for motility, $\mathrm{H}_{2} \mathrm{~S}$ production, and citrate utilization.

\section{Pathological examination}

All animals were examined for histopathological lesions. Specimens from the trachea, lung, heart, liver, spleen, kidney, adrenal gland, pancreas, esophagus, stomach, duodenum, and small and large intestines were aseptically removed. The sections were fixed in 10\% neutral buffered formalin, embedded in paraffin, and sectioned at a 5- $\mu$ m thickness. Sections were stained with haematoxylin and eosin or Masson trichrome using standard procedures, and examined for microscopic lesions.

\section{Statistical analysis}

All statistical analyses were performed with EZR (Saitama Medical Center, Jichi Medical University, Saitama, Japan), which is a graphical user interface for $\mathrm{R}$ (The R Foundation for Statistical Computing, Vienna, Austria). More precisely, it is a modified version of $\mathrm{R}$ commander designed to add statistical functions frequently used in biostatistics.

\section{Results}

\section{Survival rate}

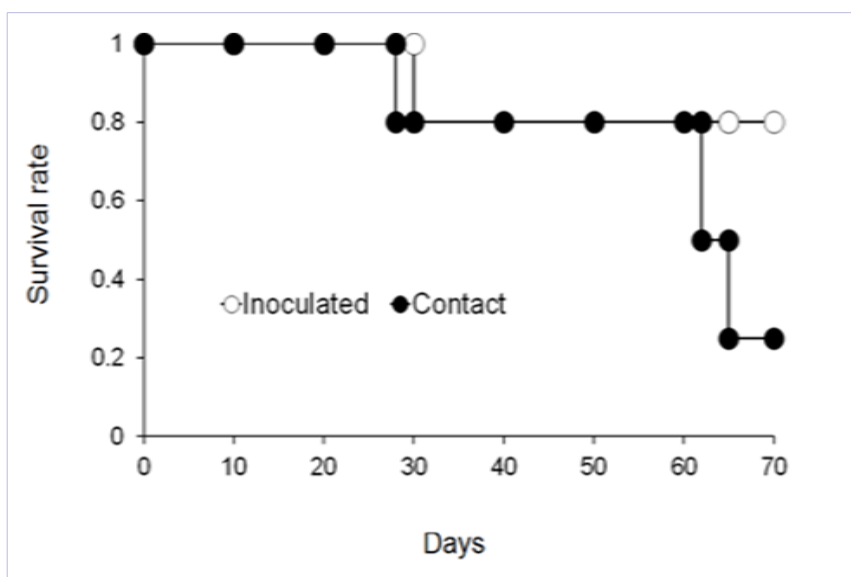

Figure 1: Comparison of the compulsive survival rate between $P$. pneumotropica-inoculated mice $(\mathrm{n}=4)$ and experimental contact mice $(n=6)$.

Figure 1 presents the compulsive survival rate of $P$. pneumotropica-inoculated mice and experimental contact mice including euthanized mice. There was no significant differences between inoculation and contact infection $(P=0.502)$. The mortality of the P. pneumotropica-inoculated (group I) and contact-infected (group II) mice were compared. The mortality of group I was $25 \%$. One mouse that died at 29 days post-inoculation was observed invasion of a large amount of bacteria in lung. The mortality of group II was $60 \%$. The dead animals in both group showed depression, ruffled coat, and weight loss before death.

\section{Histopathological findings in mice}

Histopathological changes in various organs in $P$. pneumotropica-inoculated (group I) and contact-infected (group II) mice were examined and compared (Table 1 and Figure 2). Except for the lungs, lesions were not detected in any other organ (Table 1). 
Table1: Histopathological findings in experimental mice

\begin{tabular}{|c|c|c|c|c|c|c|c|c|c|c|}
\hline \multirow[b]{2}{*}{ Group } & \multirow[b]{2}{*}{ Number } & \multirow[b]{2}{*}{ Cage } & \multirow{2}{*}{$\begin{array}{l}\text { Days after } \\
\text { inoculation } \\
\text { or contact }^{3}\end{array}$} & \multirow[b]{2}{*}{$\begin{array}{l}\text { Cardio- } \\
\text { vascular }\end{array}$} & \multicolumn{2}{|c|}{ Respiratory } & \multirow[b]{2}{*}{ Digestive } & \multirow[b]{2}{*}{ Urogenital } & \multirow[b]{2}{*}{$\begin{array}{c}\text { Hemato- } \\
\text { poietic }\end{array}$} & \multirow[b]{2}{*}{ Endocrine } \\
\hline & & & & & Trachea & Lung & & & & \\
\hline I. & $\begin{array}{l}1 \\
2 \\
3 \\
4\end{array}$ & $\begin{array}{l}\text { A } \\
\text { A } \\
\text { B } \\
\text { B }\end{array}$ & $\begin{array}{c}35 \\
35 \\
29^{\mathrm{b}} \\
70\end{array}$ & $\begin{array}{l}- \\
- \\
- \\
-\end{array}$ & $\begin{array}{l}- \\
- \\
- \\
-\end{array}$ & $\begin{array}{c}- \\
- \\
+^{\mathrm{c}} \\
+^{\mathrm{d}}\end{array}$ & $\begin{array}{l}- \\
- \\
-\end{array}$ & $\begin{array}{l}- \\
- \\
-\end{array}$ & $\begin{array}{l}- \\
- \\
- \\
-\end{array}$ & $\begin{array}{l}- \\
- \\
-\end{array}$ \\
\hline II. & $\begin{array}{c}5 \\
6 \\
7 \\
8 \\
9 \\
10\end{array}$ & $\begin{array}{l}\text { A } \\
\text { A } \\
\text { A } \\
\text { B } \\
\text { B } \\
\text { B }\end{array}$ & $\begin{array}{c}35 \\
27^{\mathrm{b}} \\
35 \\
63^{\mathrm{b}} \\
70^{0} \\
65^{\mathrm{b}}\end{array}$ & $\begin{array}{l}- \\
- \\
- \\
- \\
- \\
-\end{array}$ & $\begin{array}{l}- \\
- \\
- \\
- \\
- \\
-\end{array}$ & $\begin{array}{c}- \\
- \\
- \\
+^{\mathrm{c}} \\
+^{\mathrm{c}} \\
+^{\mathrm{c}}\end{array}$ & $\begin{array}{l}- \\
- \\
- \\
- \\
- \\
-\end{array}$ & $\begin{array}{l}- \\
- \\
- \\
- \\
- \\
-\end{array}$ & $\begin{array}{l}- \\
- \\
- \\
- \\
-\end{array}$ & $\begin{array}{l}- \\
- \\
- \\
- \\
- \\
-\end{array}$ \\
\hline III. & $\begin{array}{l}11 \\
12\end{array}$ & $\begin{array}{l}\mathrm{C} \\
\mathrm{C}\end{array}$ & $\begin{array}{l}70 \\
70\end{array}$ & - & - & - & - & - & - & - \\
\hline \multicolumn{11}{|c|}{$\begin{array}{l}\text { Cardiovascular: heart. Digestive: esophagus-intestine, liver. Urogenital: kidney, uterus. Hematopoietic: thymus, spleen. } \\
\text { Endocrine: adrenal gland. }{ }^{3} \text { Days after Pasteurella pneumotropica-inoculated or after contact infection. } \\
\text { bDead mouse. }{ }^{\text {cabscesses. }}{ }^{\mathrm{d}} \text { small abscesses. }\end{array}$} \\
\hline
\end{tabular}

For group I, the mouse (No. 3) that died at 29 days post inoculation had lung abscesses. The two mice (Nos. 1 and 2) that were euthanized at 35 days had no lesions, but the mouse (No. 4) that was euthanized at 70 days showed small abscesses. Meanwhile, in group II mice, lung lesions were not recognized within 35 days after contact regardless of natural death or euthanasia (Nos. 5, 6, and 7). However, after 35 days, the dead (Nos. 8 and 10) and euthanized mice (No. 9) had abscesses in lung.

The histopathological lesions of lung abscesses are shown in Figure 2. Photomicrographs of most the severe lesions from group I (No. 3) and group II (No. 10) mice are shown. The severity of abscess lesions in mouse No. 3 (group I) was greater than that of mouse No. 10 (group II). The left lung of mouse No. 3 harbored many abscesses and the range of respiratory activities was very narrow (Figure 2A). Lung tissues were collapsed and a large number of inflammatory cells were observed (Figure 2B). Regarding mouse No. 10, the abscesses of the right lung spread to the right upper side (Figure 2C). In the lung tissues, a large amount of inflammatory cell infiltration was observed (Figure 2D). Furthermore, many pale blue Giemsa stain-positive bacterial colonies were observed.

\section{Bacterial isolation from mouse organs}

A comparison of $P$. pneumotropica distribution in respiratory organs and blood of mice between $P$. pneumotropicainoculated (group I) and contact-infected (group II) mice is shown in Table 2. Regarding euthanized mice of group I (Nos. 1,2, and 4), P. pneumotropica was isolated from the upper respiratory organs

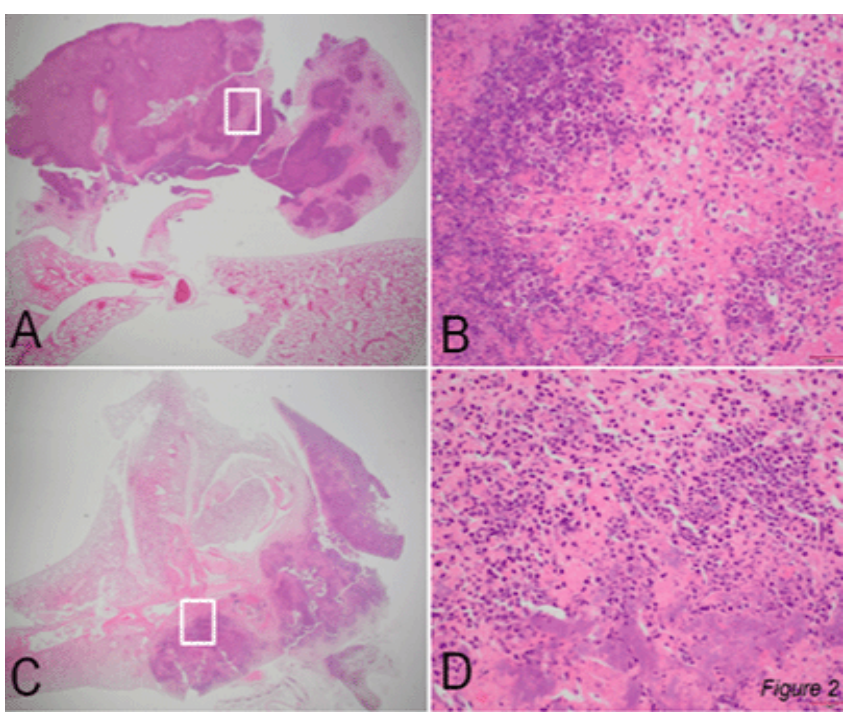

Figure 2: Histopathological findings in the lungs of mice by H\&E staining. A) Pasteurella pneumotropica-inoculated mice (group I, No. 3). The upper part indicates the left lung. Most of the left lung (upper part) was occupied by many abscesses, and lobe respiration function was not recognized (1x). B) The white square of A. The lung tissues were collapsed, and a large amount of inflammatory cell infiltration was observed (400x). C) Contact-infected mice (group II, No. 10). The abscesses of the right lung spread to the right upper side (1x). D) The white square of $C$. A large number of inflammatory cells were present. Many positive bacterial colonies (pale blue, based on Giemsa staining) can be seen (400x). 
(nasal cavity conjunctiva, oral cavity, and laryngopharynx), but not from the lower respiratory organs (trachea and lung). Regarding group II, bacterial isolation from euthanized mice (Nos. 5 and 7) at 35 days after contact was similar to that of group I; however, mice euthanized at 70 days carried the bacteria in their upper and lower respiratory organs. From mice that died naturally, bacteria were cultured from the upper and lower respiratory organs, regardless of inoculation method (group I or II).

Table 2: Isolation of $P$. pneumotropica in experimental mice

\begin{tabular}{|c|c|c|c|c|c|c|c|c|c|}
\hline \multicolumn{10}{|c|}{ P. pneumotropica isolation } \\
\hline Group & Number & $\begin{array}{c}\text { Days after } \\
\text { inoculation or } \\
\text { contact }^{3}\end{array}$ & $\begin{array}{l}\text { Nasal } \\
\text { Cavity }\end{array}$ & $\begin{array}{l}\text { Respiratory } \\
\text { Conjunctiva }\end{array}$ & $\begin{array}{c}\text { Oral } \\
\text { Cavity }\end{array}$ & $\begin{array}{c}\text { Pharyngo- } \\
\text { larynx }\end{array}$ & Trachea & Lung & Blood \\
\hline \multirow{4}{*}{ I. } & 1 & 35 & $+^{\mathrm{b}}$ & + & + & + & - & - & - \\
\hline & 2 & 35 & + & + & + & + & - & - & - \\
\hline & 3 & $29^{c}$ & + & - & + & - & + & $t^{d}$ & $\mathrm{NT}^{\mathrm{e}}$ \\
\hline & 4 & 70 & + & + & + & + & - & - & - \\
\hline \multirow{6}{*}{ II. } & 5 & 35 & - & + & + & + & - & - & - \\
\hline & 6 & $27^{c}$ & + & + & + & + & + & + & NT \\
\hline & 7 & 35 & + & + & + & + & - & - & - \\
\hline & 8 & $63^{c}$ & + & + & + & + & + & + & NT \\
\hline & 9 & 70 & + & + & + & + & + & - & + \\
\hline & 10 & $65^{c}$ & + & + & + & + & + & + & NT \\
\hline \multirow{2}{*}{ III. } & 11 & 70 & - & - & - & - & - & - & - \\
\hline & 12 & 70 & - & - & - & - & - & - & - \\
\hline
\end{tabular}

${ }^{3}$ inoculation: after Pasteurella pneumotropica-inoculated, contact: after contact infected. ${ }^{\mathrm{b}+}$ : positive, - : negative.

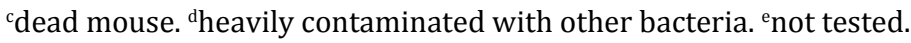

\section{Discussion}

Our study developed an experimental contact infection model for the study of pathogenesis of $P$. pneumotropica in NOD/ShiJic-scid mice. The mice demonstrated a decrease in body weight, lung lesions, and death, based on observations of clinical signs, histopathological investigations, and detection of P. pneumotropica. To the best of our knowledge, experimental contact infection of $P$. pneumotropica in mice has not been reported previously. However, investigators have reported the transmission of P. pneumotropica [15-16].

The experimental contact infection of $P$. pneumotropica resembled natural infection more so than other experimental methods. In this study, the death rates calculated by the compulsive survival rates in contact infection were $60 \%$. Those of intranasal inoculation were $25 \%$. This difference could be based on dispersion volumes of intranasal inoculation. The death rates of intranasal inoculation agreed with those of our previous study [7]. The results reinforced the results of a previous study of NOD/Shijic-scid mice inoculated with P. pneumotropica strain ATCC 35149 , which reported death rates of $25 \%$. These results indicate that mice with contact infection are thought to be more aggravated than artificially inoculated mice. The mechanisms underlying these results should be clarified in future study.

All mice demonstrated decreases in body weight before natural death regardless of inoculation method (intranasal or contact-induced). The results showed that the major clinical sign of $P$. pneumotropica infection in NOD/Shijic-scid mice was a decrease in body weight; the cause for this remains unknown.

Intranasal inoculation of $P$. pneumotropica resulted in lung abscess lesions. This result is in agreement with that of our previous study [7]. Similarly, upon contact infection, the lesions were similar to those of intranasal inoculation. Lesions were not found in any organ tested (except for lung). These results suggest that the bacteria may exhibit tropism to the lung. In this contactinfection model, respiratory failure due to lung abscesses may be the cause of death. Regardless of intranasal inoculation or contact infection, all mice that died from infection had lung abscesses except for one mouse. The degree of lung abscess lesions upon nasal inoculation was greater than that of contact infection, but the frequency of lesion occurrence was numerically higher in the contact infection mice compared to that of the nasal inoculation group.

All mice, which died naturally and exhibited body weight loss and lung abscess lesions, carried $P$. pneumotropica in their lower respiratory tract (trachea and lung). This result demonstrates that multiplication of the bacteria in the upper respiratory tracts results in invasion of the lower respiratory tracts due to the inhibition of the host immune system. The results of $P$. pneumotropica isolation from the upper respiratory tracts (nasal cavity, conjunctiva, oral cavity, and laryngopharynx) for intranasal inoculation and contact infection were similar. In contrast, isolation of bacteria from the lower respiratory tract was 
different between groups. From mice euthanized at 70 days after inoculation, P. pneumotropica was not isolated from the intranasal infection group, but the bacteria were isolated at 70 days in the contact-infected group. In this study, minimum number of mice and no repetition was conducted; these intendancy should be clarified in future study.

The development of a contact infection model in this study is of great significance for understanding the pathogenesis of P. pneumotropica infection in mice. We are currently investigating the virulence factors of $P$. pneumotropica. In our previous studies, several RTX toxins have been identified in these bacteria $[19,20]$. Furthermore, several candidate virulence-associated genes such as RTX toxins were identified from a draft genome sequence of P. pneumotropica $[21,22]$. The contact infection model developed in this study will enable us to investigate the effect of virulence factors such as RTX toxins in vivo.

In developing countries, many pathogens of laboratory animals are opportunistic organisms [23]. Pseudomonas aeruginosa, Helicobacter hepaticus, and Staphylococcus aureus are opportunistic organisms. However, the pathogenicity of these organisms remains unclear. The contact infection method in this study would provide a means to research the pathogenicity of such organisms.

In this study, we observed that $P$. pneumotropica could be transmitted to scid mice upon contact. Further work is required to investigate experimental contact infection using other strains of immunodeficient or immunocompetent mice. The work will contribute to our understanding of the pathogenesis of P. pneumotropica and the effects of the immune systems in mice.

\section{Declarations}

\section{Ethics approval and consent to participate}

All animal experimental procedures were performed in accordance with institutional, science community, and national guidelines for animal experimentation. In addition, the Institutional Animal Care and Use Committee (IACUC) of Tokyo Medical University approved all procedures described here (No. 381). This study does not contain any human data. For the consent to participate there is not applicable.

\section{Acknowledgments}

We would like to thank Naoko Ohnishi and Emi Okiyama for excellent technical assistance. This work was supported by Grants-in-Aid (Nos. 1408097 and 16K07095) from JSPS KAKENHI.

\section{References}

1. Olsen I, Dewhirst FE, Paster BJ, Busse H-J. Family I. Pasteurellaceae Pohl 1981b, 382VP. In: Brenner DJ, Krieg NR, Staley JT, editors. Bergey's Manual of Systematic Bacteriology, 2nd ed., Vol. 2, Part B. New York (NY): Springer. 2005;851-912.

2. Boot R, Bisgaard M. Reclassification of 30 Pasteurellaceae strains isolated from rodents. Lab Anim. 1995;29(3):314-319.
3. Christensen H, Bisgaard M. Taxonomy and biodiversity of members of Pasteurellaceae. In: Kuhnert, Christensen (editors). Pasteurellaceae. Caister Academic Press. 2008;1-26.

4. Mikazuki K, Hirasawa T, Chiba H, Takahashi K, Sasaki Y, Ohhara S, et al. Colonization pattern of Pasteurella pneumotropica in mice with latent pasteurellosis. Exp Anim. 1994;43:375-379.

5. Artwohl JE, Flynn JC, Bunte RM, Angen O, Herold KC. Outbreak of Pasteurella pneumotropica in a closed colony of STOCK-Cd28tm1Mak mice. Contemp. Top. Lab Anim Sci. 2000;39:39-41.

6. Chapes SK, Mosier DA, Wright AD, Hart ML. MHCII, Tlr4 and Nramp 1 genes control host pulmonary resistance against the opportunistic bacterium Pasteurella pneumotropica. J Leuc Biol. 2001;69:381-386.

7. Kawamoto E, Sasaki H, Okiyama E, Kanai T, Ueshiba H, Ohnishi N, et al. Pathogenicity of Pasteurella pneumotropica in immunodeficient NOD/Shijic-scid/Jcl and immunocompetent Crlj:CD1 (ICR) mice. Exp Anim. 2011;60(5):463-470.

8. Macy JD Jr, Weir EC, Compton SR, Shlomchik MJ, Brownstein DG. Dual infection with Pneumocystis carinii and Pasteurella pneumotropica in B cell-deficient mice: diagnoses and therapy. Comp Med. 2000;50(1):49-55.

9. Moore GJ, Aldred P. Treatment of Pasteurella pneumotropica abscesses in nude mice (nu/nu). Lab Anim. 1978;12(4):227-228.

10. Moore GJ. Conjunctivitis in the nude rat (rnu/rnu). Lab Anim. 1979;13(1):35.

11. Hart ML, Mosier DA, Chapes SK. Toll-like receptor 4-positive macrophages protect mice from Pasteurella pneumotropica-induced pneumonia. Infect Immun. 2003;71(2):663-670.

12. Sasaki H, Ishikawa H, Kojima K, Itoh M, Matsumoto T, Itoh $\mathrm{T}$, et al. Intranasal immunization with a non-adjuvanted adhesive protein descended from Pasteurella pneumotropica and its preventive efficacy against opportunistic infection in mice. Vaccine. 2013;31(48):57295735.

13. Giese M, Harder TC, Teifke JP, Klopfleisch R, Breithaupt A, Metteneiter TC, et al. Experimental infection and natural contact exposure of dogs with avian influenza virus (H5N1). Emerg Infect Dis. 2008;14(2):308310.

14. Yagyu K, Yanagawa R, Matsura Y, Noda H. Contact infection of mink with influenza A viruses of avian and mammalian origin. Arch Virol. 1981;68(2):143-145.

15. Nakagawa M, Saito M, Kohjima K. Mutual transmission of $P$. pneumotropica between mice and rats. Jpn J Vet Sci. 1981;43:937940.

16. Scharmann W, Heller A. Survival and transmissibility of Pasteurella pneumotropica. Lab Anim. 2001;35(2):163-166.

17. Kawamoto E, Okiyama E, Sasaki H, Sawada T, Mikazuki K, Ueshiba H. Ultrastructural characteristics of the external surfaces of Pasteurella pneumotropica from mice and Pasteurella multocida from rabbits. Lab Anim. 2007;41(2):285-291.

18. Sasaki H, Kawamoto E, Tanaka Y, Sawada T, Kunita K, Yagami K. Comparative analysis of Pasteurella pneumotropica isolates from laboratory mice and rats. Antonie Van Leeuwenhoek. 2009;95(4):311- 
317.

19.Sasaki H, Kawamoto E, Tanaka Y, Sawada T, Kunita K, Yagami K. Identification and characterization of hemolysin-like proteins similar to RTX toxin in Pasteurella pneumotropica. J Bacteriol. 2009;191(11):3698-3705.

20. Sasaki H, Ishikawa H, Sato T, Sekiguchi S, Amao H, Kawamoto E, et al. Molecular and virulence characteristics of an outer membraneassociated RTX exoprotein in Pasteurella pneumotropica. BMC Microbiol. 2011;11:55.
21. Sasaki H, Ishikawa $H$, Asano R, Ueshiba H, Matsumoto T, Boot R, et al. Draft genome sequence of the rodent opportunistic pathogen Pasteurella pneumotropica ATCC 35149T. Genome Announc. 2014;2(4). pii: e00771-14.

22. Sasaki H, Ishikawa H, Terayama H, Asano R, Kawamoto E, Ishibashi $H$, et al. Identification of a virulence determinant that is conserved in the Jawetz and Heyl biotypes of [Pasteurella] pneumotropica. Pathog Dis. 2016;74(6):ftw066.

23. Baker DG. Natural pathogens of laboratory mice, rats, and rabbits and their effects on research. Clin Microbiol Rev. 1998;11(2):231-266. 